\title{
OPTIMASI PRIMER SINGLE NUCLEOTIDE AMPLIFIED POLYMORPHYSM (SNAP) PADA GEN BRASSINOSTEROID (BRI) KELAPA SAWIT
}

\author{
Roberdi*, Ogi Ajitiyo Ramadhan \\ Laboratorium Bioteknologi, SMART Biotechnology Center Sentul Bogor, Jawa Barat \\ *e-mail: roberdi_siberakuno@yahoo.co.uk
}

\begin{abstract}
Optimisation of Single Nucleotide Amplified Polymorphism (SNAP) Primers in Brassinosteroid (BRI) Gene of Oil Palm
\end{abstract}

\begin{abstract}
Oil palm varieties that have high yields still have a high rate of stem height increase, and it has an impact on difficulties at harvest. Brassinosteroid (BRI) is one of the growth hormones that regulate stem height increase. In this study, the sample used is three types of oil palm, namely E. guineensis which represents the height growth of normal oil palm stems, E. oleifera which represents slow stem height growth, and the result of crossing or hybrid Eo x Eg which is expected to inherit the traits between the two the crossed parent. Sequencing was carried out on samples using a specific primer for the BRI gene that triggers elongation and division of stem cells. The Single Nucleotide Amplified Polymorphisms (SNAP) primers used in the analysis process need to find the optimum temperature to obtain the optimum PCR conditions. Four primers of Single Nucleotide Amplified Polymorphism (SNAP) that get the optimum temperature with a mixture of normal reagents are BRI 69 Alt-Rev and BRI 562 Ref-Rev at $55^{\circ} \mathrm{C}$, BRI $1206 \mathrm{Alt}$-Rev at $57^{\circ} \mathrm{C}$ and BRI $1206 \mathrm{Ref}-\mathrm{Rev}$ at $58^{\circ} \mathrm{C}$. Two primers require additional $\mathrm{MgCl}_{2}$ in the reactant mixture, namely BRI $69 \mathrm{Ref}-\mathrm{Rev}$ at $55^{\circ} \mathrm{C}$ and BRI 2115 Alt-Rev at $56^{\circ} \mathrm{C}$.
\end{abstract}

Keywords: Oil palm, Brassinosteroid, Primer, DNA, Genes

\begin{abstract}
ABSTRAK
Varietas-varietas kelapa sawit yang memiliki daya hasil tinggi umumnya masih memiliki laju pertambahan tinggi yang relatif cepat dan berakibat pada kesulitan saat panen. Brassinosteroid (BRI) merupakan salah satu hormon pertumbuhan yang mengatur pertambahan tinggi batang. Pada studi ini, Sampel yang digunakan adalah tiga jenis kelapa sawit yaitu sampel E. guineensis yang mewakili pertumbuhan tinggi batang kelapa sawit normal, E. oleifera yang mewakili pertumbuhan tinggi batang lambat, dan hasil persilangan atau hibrida $E O$ x $E g$ yang diharapkan mewarisi sifat antara kedua induk yang disilangkan. Sekuensing dilakukan pada sampel menggunakan primer spesifik gen BRI yang memicu pemanjangan dan pembelahan sel batang. Primer Single Nucleotide Amplified Polymorphisms (SNAP) yang digunakan dalam proses analisis perlu dicari suhu optimumnya agar didapatkan kondisi PCR yang optimum sehingga dihasilkan produk PCR yang spesifik. Empat primer Single Nucleotide Amplified Polymorphism (SNAP) yang mendapatkan suhu optimum dengan campuran pereaksi normal yaitu BRI 69 Alt-Rev dan BRI 562 Ref-Rev pada suhu $55^{\circ} \mathrm{C}$, BRI 1206 Alt-Rev pada suhu $57^{\circ} \mathrm{C}$ dan BRI 1206 Ref-Rev pada suhu $58^{\circ} \mathrm{C}$. Dua primer membutuhkan tambahan $\mathrm{MgCl}_{2}$ pada campuran pereaksinya yaitu BRI 69 Ref-Rev pada suhu $55^{\circ} \mathrm{C}$ dan BRI 2115 Alt-Rev pada suhu $56^{\circ} \mathrm{C}$.
\end{abstract}

Kata Kunci: Kelapa sawit, Brassinosteroid, Primer, DNA, Gen

\section{PENDAHULUAN}

Kelapa sawit merupakan komoditas perkebunan dengan perkembangan cukup pesat dibandingkan komoditas lainnya di Indonesia. E. guineensis lebih banyak dibudidayakan karena produksi minyak dan tandan buah segar yang tinggi dibandingkan E. oleifera. Namun E. oleifera memiliki keunggulan pada kualitas minyak dan pertambahan tinggi batang yang lebih lambat (Corley dan Tinker, 2015).
Varietas-varietas kelapa sawit yang memiliki daya hasil tinggi dan telah dilepas di Indonesia umumnya masih memiliki laju pertambahan tinggi yang relatif cepat. Ratarata pertambahan tinggi varietas-varietas kelapa sawit komersial di Indonesia yaitu 50 - $70 \mathrm{~cm}$ per tahun. Hal ini berarti pada usia 20 tahun tinggi tanamannya mencapai 10 14 meter. Tandan buah kelapa sawit yang memiliki tinggi batang lebih dari 10 meter akan mempersulit proses panen dan dikhawatirkan meningkatkan resiko 
kecelakaan jatuhnya tandan ke arah pemanen (Natawijaya, 2018).

Gen pengatur kekerdilan tanaman sangat berkaitan dengan biosintesis hormon pertumbuhan tanaman seperti giberelin (GIB), auksin (AUX), dan brassinosteroid (BRI) dengan fungsi spesifiknya masingmasing. Analisis difokuskan pada hormon BRI yang juga berperan dalam mengontrol pertambahan tinggi batang kelapa sawit. Analisis gen BRI menggunakan pendekatan molekuler yang berkaitan dengan pertambahan tinggi batang kelapa sawit. DNA tanaman sampel diamplifikasi menggunakan primer yang dikembangkan dari gen-gen yang terlibat pada proses pertambahan tinggi batang untuk mencari lokus atau posisi Single Nucleotide Polymorphism (SNP) pada kromosom. SNP pada suatu gen dapat membentuk alel yang menyebabkan perbedaan penampilan di antara individu dalam satu populasi, begitu juga pada tanaman. SNP ditentukan dari hasil sekuensing gen target yang sama pada sampel yang berbeda berupa perbedaan basa nitrogen pada urutan pasang basa tertentu. Gen terkait pertambahan tinggi batang pada kelapa sawit telah diperoleh melalui analisis bioinformatika dan dari jurnal yang telah dipublikasi. Pada studi ini, sekuensing dilakukan pada sampel kelapa sawit $E$. guineensis, E. oleifera, dan hibrida Eo $x$ Eg menggunakan primer spesifik gen BRI yang memicu pemanjangan dan pembelahan sel batang.

SNP yang ditemukan dari sekuensing harus divalidasi karena dikhawatirkan adanya potensi kesalahan pada sekuensing atau kesalahan pada penjajaran sekuen genom. Salah satu cara memvalidasi SNP adalah mengkonversinya menjadi Single Nucleotide Amplified Polymorphisms (SNAP) marker. Metode SNAP digunakan karena saat ini sedang berkembang dalam penerapannya pada berbagai organisme, didukung oleh penggunaan yang mudah dan biaya yang murah (Mubarok, 2015).

Primer yang digunakan dalam proses analisis perlu dicari suhu optimumnya agar didapatkan kondisi PCR yang optimum sehingga dihasilkan produk PCR yang spesifik. Suhu pada tahap annealing menjadi faktor penting yang mempengaruhi keberhasilan primer menempel pada utas DNA untuk mengamplifikasi gen target (Ludyasari, 2016). Studi ini dilakukan dalam upaya pencarian SNP dan pengembangan marka SNAP pada gen-gen terkait pertambahan tinggi batang pada kelapa sawit.

\section{BAHAN DAN METODE}

\section{Bahan dan Alat}

Bahan-bahan yang digunakan antara lain sampel daun kelapa sawit, kit isolasi DNA Nucleospin Plant II ${ }^{T M}$ merek Macherey-Nagel, nitrogen cair, alkohol 70\%, DNA Taq Polymerase PCR Kit merek Fermentas, 18 pasang primer berkode BRI Ref-Alt-Rev, akuades steril, buffer TE, agarosa, buffer TAE, marka Generuler $1 \mathrm{~kb}$, 6x Loading Dye dan GelRed. Alat-alat yang digunakan antara lain 1,5 mL dan 2,0 mL tube, PCR tube, tips putih dan kuning, pipet mikro Eppendorf ukuran 1-10 $\mu \mathrm{L}, 10-100$ $\mu \mathrm{L}$ dan 100-1000 $\mu \mathrm{L}$, mortar, alat sentrifugasi merek Thermo Scientific, homogenizer merek Vortex, inkubator Isotemp merek Fisher Scientific, spektrofotometer NanoDrop 2000c merek Thermo Scientific, PCR merek Applied Biosystems, neraca analitik, microwave, Erlenmeyer, elektroforesis merek Advance dan GelDoc merek Bio-Rad.

\section{Metode \\ Isolasi DNA (Macherey-Nagel, 2014)}

Isolasi DNA dilakukan menggunakan Kit Nucleospin Plant II ${ }^{T M}$ (Macherey-Nagel, Jerman). Sampel daun kelapa sawit dibersihkan dengan alkohol $70 \%$ dan dibuang tulang daunnya. Sebanyak $100 \mathrm{mg}$ sampel daun digerus dengan bantuan nitrogen cair sampai halus. Hasil gerusan lalu dimasukan ke dalam tube $2 \mathrm{~mL}$, ditambahkan $400 \mu \mathrm{L}$ buffer PL1, digoyang perlahan agar sampel tercampur rata dengan buffer, lalu sampel di-vortex agar homogen. Sebanyak $10 \mu \mathrm{L}$ RNAse ditambahkan ke dalam campuran, setelah itu diinkubasi selama 10 menit pada suhu $65^{\circ} \mathrm{C}$. Campuran disentrifugasi pada kecepatan $11.000 \mathrm{x} \mathrm{g}$ selama 1 menit. 
Nucleospin filter (cincin ungu) dipasang ke tabung koleksi baru. Supernatan dimasukan ke dalam Nucleospin filter, disentrifugasi pada kecepatan $11.000 \mathrm{x} \mathrm{g}$ selama 1 menit. Supernatan pada tabung koleksi disimpan dan filter dibuang. Sebanyak $450 \mu \mathrm{L}$ buffer PC ditambahkan lalu diresuspensi dengan pipet mikro. Nucleospin Plant II column (cincin hijau) dipasang ke tabung koleksi baru. Sebanyak $750 \mu \mathrm{L}$ campuran dimasukkan ke column, disentrifugasi pada kecepatan $11.000 \mathrm{x} \mathrm{g}$ selama 1 menit. Supernatan pada tabung koleksi lalu dibuang.

Sebanyak $400 \quad \mu \mathrm{L}$ buffer PW 1 ditambahkan ke dalam column, disentrifugasi pada kecepatan $11.000 \mathrm{x} \mathrm{g}$ selama 1 menit. Supernatan pada tabung koleksi lalu dibuang. Sebanyak $700 \mu \mathrm{L}$ buffer PW 2 ditambahkan ke dalam column lalu disentrifugasi pada kecepatan $11.000 \mathrm{x}$ g selama 1 menit. Supernatan pada tabung koleksi lalu dibuang. Nucleospin Plant II column dipasang ke tabung $2 \mathrm{~mL}$ baru. Sebanyak $100 \mu \mathrm{L}$ buffer PE yang sudah diinkubasi pada suhu $65^{\circ} \mathrm{C}$ ditambahkan lalu disentrifugasi pada kecepatan $11.000 \mathrm{x} \mathrm{g}$ selama 1 menit.

\section{Pengukuran Konsentrasi DNA Hasil Isolasi}

Pengukuran konsentrasi DNA dilakukan setelah proses isolasi DNA selesai menggunakan spektrofotometer Nanodrop 2000c (Thermo Scientific). Blanko yang digunakan adalah pelarut pada saat isolasi DNA yaitu buffer PE dari kit MachereyNagel sebanyak $1 \mu \mathrm{L}$, diteteskan pada bagian sensor, lalu ditekan tombol F3 pada keyboard komputer untuk mengukur blanko. Bagian sensor kemudian dibersihkan menggunakan tisu. Sebanyak $1 \mu \mathrm{L}$ sampel diteteskan menggunakan pipet pada bagian sensor. Pada keyboard komputer ditekan F1 untuk mengukur sampel. Setiap setelah pengukuran sampel sensor selalu dibersihkan dengan tisu. Hasil konsentrasi yang terukur dalam satuan $\mathrm{ng} / \mu \mathrm{L}$. Selain konsentrasi DNA, hasil pengukuran juga menampilkan kemurnian DNA dari nilai perbandingan absorbansi pada panjang gelombang $260 \mathrm{~nm}$ dan $280 \mathrm{~nm}$. DNA dapat dikatakan murni apabila nilai perbandingan 260/280 berkisar antara 1,8 hingga 2,0.

\section{Pengenceran Sampel DNA}

Pengenceran DNA dilakukan bila konsentrasi DNA lebih dari $40 \mathrm{ng} / \mu \mathrm{L}$. Tujuan dari pengenceran agar saat melakukan PCR setiap sampel memiliki konsentrasi yang sama dan sebagian DNA hasil isolasi dijadikan stok untuk pemakaian selanjutnya. Pengenceran dilakukan dengan rumus $\mathrm{V}_{1} \cdot \mathrm{M}_{1}=\mathrm{V}_{2} \mathrm{M}_{2}$ dengan penambahan $\mathrm{ddH}_{2} \mathrm{O}$ sesuai dengan perhitungan yang sudah ditetapkan.

\section{Optimasi Primer}

Optimasi primer bertujuan untuk mendapatkan suhu annealing yang optimum pada masing-masing primer. Optimasi primer menggunakan kit PCR DNA Taq Polymerase merek Fermentas dengan kombinasi campuran reaksi terdiri dari 1,5 $\mu \mathrm{L}$ buffer PCR (200 mM Tris-HCl pH 8.4, $500 \mathrm{mM} \mathrm{KCl}) 10 \mathrm{X}, 1,5 \mu \mathrm{L}$ dNTP $100 \mathrm{mM}$, $0,6 \mu \mathrm{L} \mathrm{MgCl}_{2} 0,5 \mathrm{M}, 1,5 \mu \mathrm{L}$ primer forward $1 \mu \mathrm{M}, 1,5 \mu \mathrm{L}$ primer reverse $1 \mu \mathrm{M}, 1 \mu \mathrm{L}$ DNA template $40 \mathrm{ng} / \mu \mathrm{L}, 0,12 \mu \mathrm{L}$ enzim Taq Polymerase $5 \mathrm{U} / \mu \mathrm{L}$, dan $7,28 \mu \mathrm{L} \quad \mathrm{H}_{2} \mathrm{O}$. Optimasi dilakukan untuk seluruh primer menggunakan rentang suhu annealing yang telah diperkirakan dari primer yang dipakai. Sampel diamplifikasi sesuai petunjuk kit. Hasil PCR kemudian dielektroforesis pada gel agarosa $1 \%$ untuk mengetahui suhu optimal dari masing-masing primer.

\section{Elektroforesis Hasil Optimasi Primer}

Setelah proses PCR selesai, kemudian dilakukan proses elektroforesis menggunakan gel agarosa $1 \%$ untuk melihat amplikon yang dihasilkan. Elektroforesis akan menunjukkan ukuran pita yang dihasilkan. Gel agarosa dipersiapkan dengan menimbang sebanyak $0.8 \mathrm{~g}$ agar, dilarutkan dengan $80 \mathrm{~mL}$ buffer TAE 1x, dicampur lalu dipanaskan dalam microwave. Setelah cukup dingin, larutan dituang ke dalam cetakan gel dan sisir pembuat sumur dipasang. Setelah gel mengeras diletakan pada chamber elektroforesis yang sudah berisi buffer TAE 1x. Sampel dimasukkan dalam well setelah dicampurkan dengan loading dye yang 
mengandung GelRed dengan perbandingan sampel dan loading dye 1:1 dengan total volume $4 \mu \mathrm{L}$. Elektroforesis dijalankan dengan tegangan $100 \mathrm{~V}$ selama 25-30 menit. Setelah selesai gel diambil dan diletakan pada alat GelDoc untuk visualisasi gel menggunakan sinar UV. GelDoc yang digunakan adalah GelDoc XR System dari Bio-Rad. Hasil foto dapat dilihat menggunakan komputer dengan perangkat lunak Quantity One.

\section{HASIL DAN PEMBAHASAN}

\section{Desain Primer}

Sebelum mendapatkan primer yang digunakan, telah lebih dulu dilakukan proses sekuensing DNA menggunakan primer SNP spesifik yang mengamplifikasi gen BRI. Gen BRI adalah gen yang berpengaruh dalam pertumbuhan tinggi batang pohon sawit. Proses sekuensing menggunakan tiga jenis sampel, yaitu sampel DNA $E$. guineensis yang mewakili pertumbuhan tinggi batang normal, E. oleifera dan hasil persilangan atau hibrida $E g$ x $E o$ yang mewakili pertumbuhan tinggi batang lambat. Setelah diperoleh hasil sekuensing DNA sampel-sampel tersebut (Gambar 1), maka lokus SNP pada ketiga jenis sampel tersebut dapat ditentukan. Kemudian hasil SNP yang telah ditentukan dapat digunakan untuk menjadi acuan membuat desain primer SNAP untuk analisis lebih lanjut. Proses desain pasangan primer SNAP dilakukan pada program WebSNAPER (Susanto et al., 2013).

Primer yang telah dibuat pada awalnya berbentuk pellet seperti kerak berwarna putih. Buffer TE ditambahkan pada primer untuk menjaga agar primer tidak mudah rusak. Buffer TE tersusun dari Tris $\mathrm{HCl}$ dan EDTA (Suguna et al., 2014). EDTA yang terdapat pada buffer TE berfungsi mengikat ion Magnesium (pengelat) yang merupakan kofaktor enzim nuclease (Campbell et al., 2002).

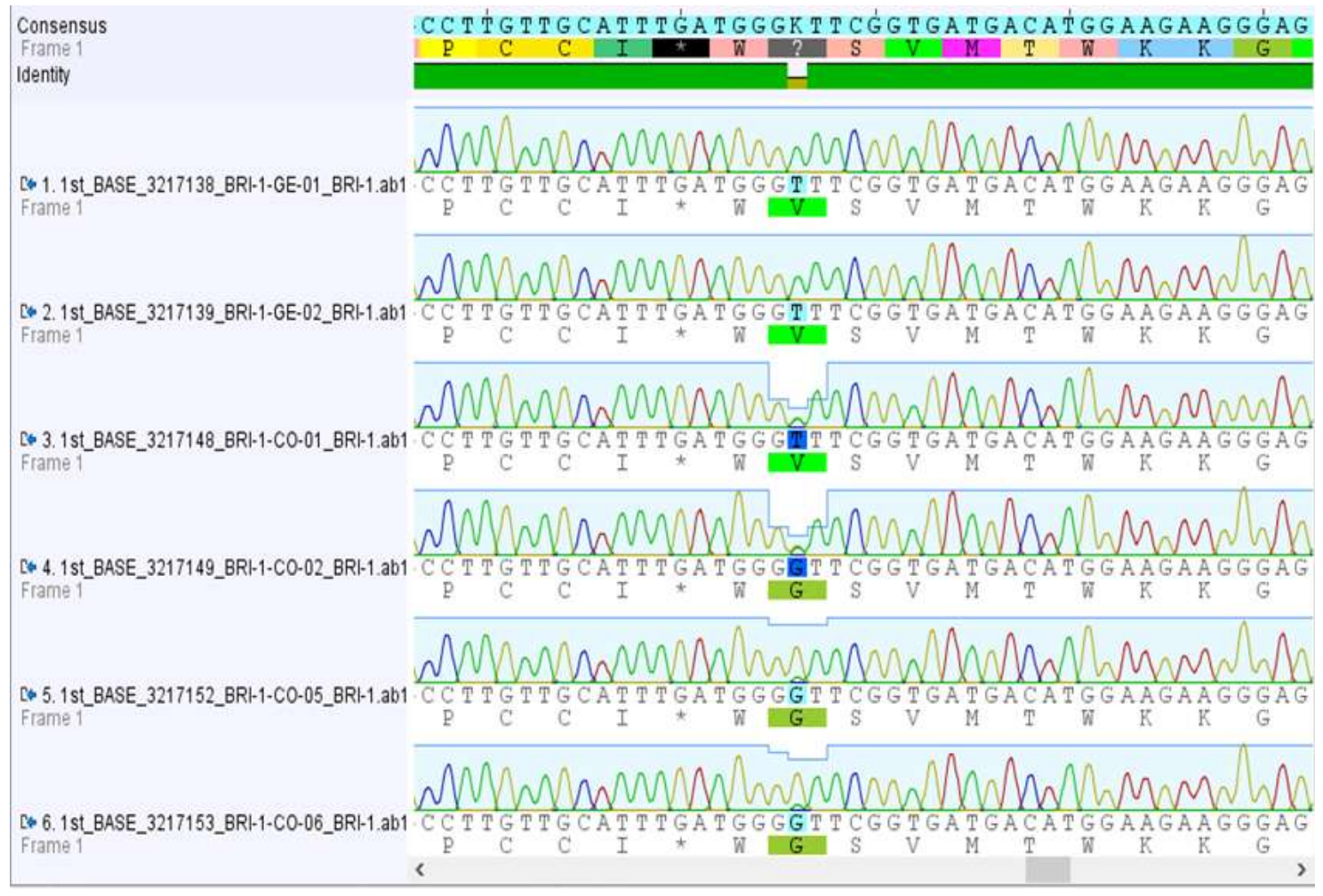

Gambar 1. Sekuensing DNA sampel E. guineensis (nomor 1-2), hibrida Eg X Eo (nomor 3-4) dan E. oleifera (nomor 5-6) 
Tabel 1. Hasil Pengukuran Konsentrasi Sampel Isolasi DNA.

\begin{tabular}{cccc}
\hline No & Kode Sampel & Konsentrasi $(\mathrm{ng} / \mu \mathrm{L})$ & A260/A280 \\
\hline 1 & Spear 1 & 112,2 & 1,94 \\
2 & Spear 2 & 120,7 & 1,88 \\
3 & Spear 3 & 100,8 & 1,85 \\
4 & Spear 4 & 111,7 & 1,98 \\
5 & Spear 5 & 151,6 & 1,92 \\
6 & BTC 1 & 56,6 & 2,02 \\
7 & BTC 2 & 30,4 & 1,92 \\
8 & BTC 3 & 62,8 & 1,87 \\
9 & BTC 4 & 35,8 & 1,76 \\
10 & BTC 5 & 20,6 & 1,89 \\
11 & Eo 1 & 23,2 & 1,78 \\
12 & Eo 2 & 27,7 & 1,84 \\
13 & Eo 3 & 40,1 & 1,81 \\
\hline
\end{tabular}

\section{Isolasi DNA}

Sampel yang digunakan adalah tiga jenis kelapa sawit yaitu sampel E. guineensis yang mewakili pertumbuhan tinggi batang kelapa sawit normal, E. oleifera yang mewakili pertumbuhan tinggi batang lambat, dan hasil persilangan atau hibrida $E o$ x $E g$ yang diharapkan mewarisi sifat antara kedua induk yang disilangkan. DNA diisolasi dari daun ketiga sampel tersebut. Isolasi DNA menggunakan sampel daun karena jaringan daun paling mudah digerus dengan bantuan nitrogen cair dibandingkan dengan bagian lainnya. DNA pada semua jaringan tanaman adalah sama, oleh karena itu diambil jaringan yang paling mudah untuk diisolasi.

Metode dalam isolasi DNA semakin berkembang dan beragam, tergantung dari jenis dan jaringan tanaman yang digunakan. Pemurnian DNA ditentukan oleh kehomogenan jaringan pada tanaman, penambahan buffer saat menggerus jaringan, dan proses penghilangan enzim yang menghambat polisakarida. (Syafaruddin et al., 2011).

Pengukuran konsentrasi DNA hasil isolasi dilakukan menggunakan spektrofotometer Nanodrop 2000c (Thermo Scientific). Spektrofotometer tipe ini mempunyai prinsip yang sama seperti spektrofotometer pada umumnya, hanya jumlah sampel ukur saja yang menjadi pembeda. Alat ini hanya membutuhkan $1 \mu \mathrm{L}$ sampel untuk melakukan pengukuran. Konsentrasi DNA diukur dengan spektrofotometer pada panjang gelombang $260 \mathrm{~nm}$, sedangkan konsentrasi protein diukur pada panjang gelombang 280. Perbandingan A260 nm dengan A280 pada pengukuran larutan DNA merupakan nilai kemurnian larutan DNA. Batas kemurnian yang biasa dipakai dalam analisis molekuler pada rasio A260/A280 adalah 1,8 - 2,0 (Syafaruddin et al., 2011). Hasil pengukuran konsentrasi DNA hasil isolasi dari sampel daun kelapa sawit disajikan pada Tabel 1.

\section{Optimasi Primer}

Primer SNAP dinyatakan berhasil jika bisa mengamplifikasi sampel hibrida dan salah satu dari sampel E.guineensis atau E. oleifera. Primer tersebut menjadi pembeda target antara E.guineensis atau E. oleifera. Primer dirancang dengan mengubah jenis basa nitrogennya pada basa keempat terdekat dari alel target. Suhu optimum primer yang direaksikan ada yang tidak perlu penambahan $\mathrm{MgCl}_{2}$, ada pula yang perlu penambahan $\mathrm{MgCl}_{2}$ sebanyak $0,5 \mu \mathrm{L}$ per reaksi. Penggunaan $\mathrm{MgCl}_{2}$ dilakukan saat hasil amplikon pada agarosa masih belum jelas dan spesifik. Data primer SNAP yang digunakan berdasarkan SNP pada gen BRI (Tabel 2.). 
Tabel 2: Daftar Primer SNAP yang Didesain Berdasarkan SNP pada Gen BRI

\begin{tabular}{|c|c|c|c|c|c|}
\hline No & ID Primer & $\mathrm{Tm}$ & $\begin{array}{c}\text { Panjang } \\
\text { Primer }\end{array}$ & $\begin{array}{c}\text { Ukuran } \\
\text { Produk (bp) }\end{array}$ & $\begin{array}{c}\text { GC Content } \\
(\%)\end{array}$ \\
\hline \multirow[t]{3}{*}{1} & BRI\#69 Ref & 54.584 & 22 & 359 & 45,4 \\
\hline & BRI\#69 Alt & 54.925 & 21 & & 52,4 \\
\hline & BRI\#69 Rev & 55.241 & 18 & & 55,6 \\
\hline \multirow[t]{3}{*}{2} & BRI\#154 Ref & 60.618 & 18 & 367 & 61,1 \\
\hline & BRI\#154 Alt & 63.394 & 18 & & 66,7 \\
\hline & BRI\#154 Rev & 54.941 & 18 & & 50 \\
\hline \multirow[t]{3}{*}{3} & BRI\#199 Ref & 56.953 & 18 & 350 & 55,6 \\
\hline & BRI\#199 Alt & 54.606 & 19 & & 47,4 \\
\hline & BRI\#199 Rev & 54.704 & 18 & & 50 \\
\hline \multirow[t]{3}{*}{4} & BRI\#435 Ref & 53.212 & 19 & 368 & 47,4 \\
\hline & BRI\#435 Alt & 55.814 & 20 & & 50 \\
\hline & BRI\#435 Rev & 54.915 & 22 & & 45,4 \\
\hline \multirow[t]{3}{*}{5} & BRI\#562 Ref & 54.572 & 19 & 330 & 63,2 \\
\hline & BRI\#562 Alt & 54.237 & 22 & & 54,5 \\
\hline & BRI\#562 Rev & 54.962 & 21 & & 47,6 \\
\hline \multirow[t]{3}{*}{6} & BRI\#649 Ref & 58.591 & 18 & 372 & 61,1 \\
\hline & BRI\#649 Alt & 56.479 & 18 & & 55,6 \\
\hline & BRI\#649 Rev & 54.852 & 18 & & 55,6 \\
\hline \multirow[t]{3}{*}{7} & BRI\#1206 Ref & 55.048 & 20 & 328 & 60 \\
\hline & BRI\#1206 Alt & 55.385 & 21 & & 52,4 \\
\hline & BRI\#1206 Rev & 54.917 & 19 & & 42,1 \\
\hline \multirow[t]{3}{*}{8} & BRI\#2046 Ref & 58.056 & 18 & 367 & 61,1 \\
\hline & BRI\#2046 Alt & 57.435 & 18 & & 55,6 \\
\hline & BRI\#2046 Rev & 55.033 & 18 & & 50 \\
\hline \multirow[t]{3}{*}{9} & BRI\#2115 Ref & 57.244 & 18 & 365 & 61,1 \\
\hline & BRI\#2115 Alt & 55.347 & 19 & & 57,9 \\
\hline & BRI\#2115 Rev & 55.034 & 19 & & 47,4 \\
\hline
\end{tabular}

Keterangan: Ref: Reference; Alt: Alternate; Rev: Reverse; \#: titik SNP

GC Content adalah perbandingan jumlah guanin dan sitosin dengan jumlah basa nitrogen keseluruhan pada primer dalam nilai persen. Setelah hasil foto pada elektroforesis didapatkan, rekap hasil dapat dijabarkan pada Tabel 3.

Berdasarkan hasil analisis, Empat primer Single Nucleotide Amplified Polymorphism (SNAP) yang mendapatkan suhu optimum dengan campuran pereaksi normal yaitu BRI 69 Alt-Rev dan BRI 562 Ref-Rev pada suhu $55^{\circ} \mathrm{C}$, BRI 1206 Alt-Rev pada suhu $57^{\circ} \mathrm{C}$ dan BRI 1206 Ref-Rev pada suhu $58^{\circ} \mathrm{C}$ (Gambar 2.). Dua primer membutuhkan tambahan $\mathrm{MgCl}_{2}$ pada campuran pereaksinya yaitu BRI 69 Ref-Rev pada suhu $55^{\circ} \mathrm{C}$ dan BRI 2115 Alt-Rev pada suhu $56^{\circ} \mathrm{C}$ (Gambar 3.). Pada analisis ini, digunakan kit DNA Taq Polymerase merek Fermentas dengan kombinasi campuran reaksi seperti yang tertera pada cara kerja. Proses PCR dijalankan pada program yang sesuai dengan prosedur kit PCR yang dipakai. Prosedur program PCR pada kit tersebut dijabarkan sebagai berikut: Denaturasi awal pada suhu $95{ }^{\circ} \mathrm{C}$ selama 1-3 menit sekali siklus, denaturasi - Annealing Extension dengan siklus diulang sebanyak 25-40 kali (suhu program secara berurutan, pada suhu $95{ }^{\circ} \mathrm{C}$ selama $30 \mathrm{~s}-\mathrm{Tm} \pm 5$ sesuai primer selama $30 \mathrm{~s}-72^{\circ} \mathrm{C}, 1$ menit), dan Final Extension pada suhu $72^{\circ} \mathrm{C}, 5-15$ menit.

Setiap komponen pada PCR memiliki fungsinya masing-masing. Enzim Taq DNA Polymerase berperan penting dalam melakukan proses tahapan dalam PCR. Enzim ini memiliki keaktifan pada suhu tinggi. Primer digunakan untuk memotong target nukleotida pada DNA target dengan memotong urutan nukleotida awal dan akhir pada DNA target. dNTP berfungsi untuk melakukan reaksi polimerisasi terhadap sekuen tertentu pada DNA target. Buffer berfungsi untuk menjaga suasana optimum rekasi PCR. $\mathrm{MgCl}_{2}$ berfungsi sebagai kofaktor bagi enzim untuk melakukan reaksi pada PCR (Hasibuan, 2015). 
Tabel 3: Elektroforesis Agarosa Primer BRI dengan Sampel Spear, BTC dan EO

\begin{tabular}{|c|c|c|c|c|c|}
\hline No & Pasangan Primer & $\begin{array}{l}\text { Spear }(E . \\
\text { guineensis) }\end{array}$ & $\begin{array}{l}\text { Hasil } \\
\text { BTC } \\
(E g X E o)\end{array}$ & $\begin{array}{c}\mathrm{EO} \\
(\text { E. oleifera })\end{array}$ & $\begin{array}{c}\text { Suhu Optimum } \\
\left({ }^{0} \mathrm{C}\right)\end{array}$ \\
\hline \multirow[t]{2}{*}{1} & BRI\#69 Ref-Rev & +++++ & +++++ & --- & $55\left(+\mathrm{MgCl}_{2}\right)$ \\
\hline & BRI\#69 Alt-Rev & ----- & +++++ & +++ & 55 \\
\hline \multirow[t]{2}{*}{2} & BRI\#154 Ref-Rev & ----- & +++++ & --- & - \\
\hline & BRI\#154Alt-Rev & +++++ & ----- & --- & - \\
\hline \multirow[t]{2}{*}{3} & BRI\#199 Ref-Rev & ----- & +++++ & --- & - \\
\hline & BRI\#199 Alt-Rev & +++++ & ----- & --- & - \\
\hline \multirow[t]{2}{*}{4} & BRI\#435 Ref-Rev & ----- & +++++ & --- & - \\
\hline & BRI\#435 Alt-Rev & +++++ & +++++ & +++ & - \\
\hline \multirow[t]{2}{*}{5} & BRI\#562 Ref-Rev & +++++ & +++++ & --- & 55 \\
\hline & BRI\#562 Alt-Rev & +++++ & +++++ & +++ & - \\
\hline \multirow[t]{2}{*}{6} & BRI\#649 Ref-Rev & ---- & ----- & --- & - \\
\hline & BRI\#649 Alt-Rev & ----- & ----- & --- & - \\
\hline \multirow[t]{2}{*}{7} & BRI\#1206 Ref-Rev & ----- & +++++ & +-+ & 58 \\
\hline & BRI\#1206 Alt-Rev & +++++ & +++-+ & --- & 57 \\
\hline \multirow[t]{2}{*}{8} & BRI\#2046 Ref-Rev & +++++ & +++++ & +++ & - \\
\hline & BRI\#2046 Alt-Rev & ----- & ----- & --- & - \\
\hline \multirow[t]{2}{*}{9} & BRI\#2115 Ref-Rev & ----- & +++++ & --- & - \\
\hline & BRI\#2115 Alt-Rev & +++++ & +++++ & --- & $56\left(+\mathrm{MgCl}_{2}\right)$ \\
\hline
\end{tabular}

Keterangan: +: mucul pita sekuen; -: tidak muncul pita sekuen

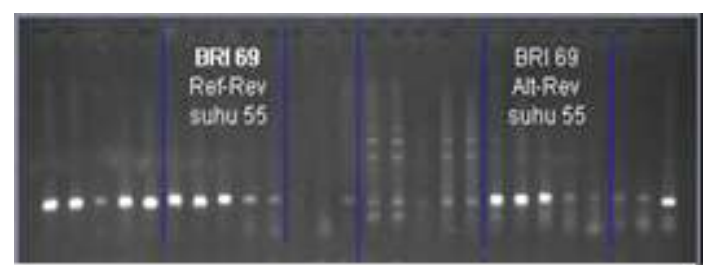

Spear BTC ET Spear BTC ET

a

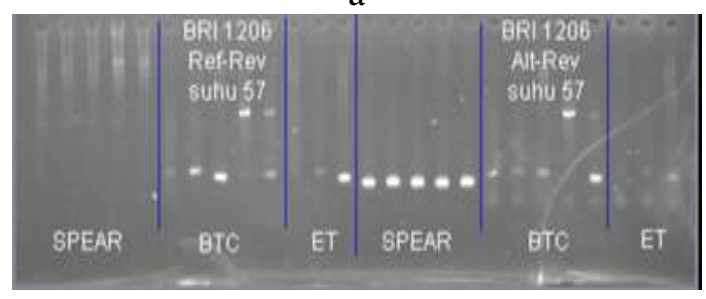

c

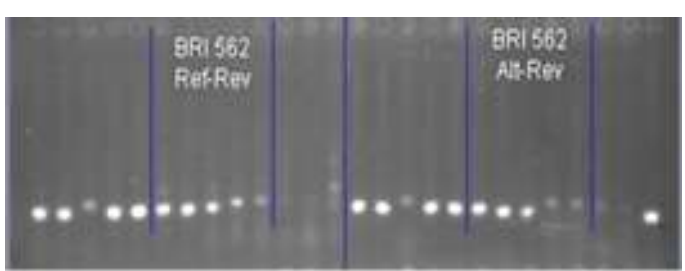

Spear BTC ET Spear BTC ET

b

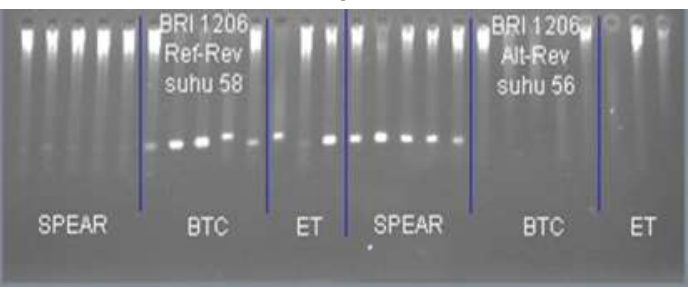

d

Gambar 2. Elektroforesis Agarosa dengan Primer (a) BRI 69 Alt-Rev dan (b) BRI 562 Ref-Rev pada Suhu $55^{\circ} \mathrm{C}$, (c) BRI 1206 Alt-Rev pada Suhu $57^{\circ} \mathrm{C}$ dan (d) BRI 1206 Ref-Rev pada Suhu $58^{\circ} \mathrm{C}$

Pengaturan siklus pada tiga tahap PCR dibuat berulang sehingga area yang dibatasi oleh dua primer diamplifikasi secara eksponensial (disebut amplikon, berupa untai ganda). Amplifikasi seperti ini akan menyebabkan tercapainya jumlah kopi yang dapat dirumuskan dengan (2n) $x$, dimana $n$ merupakan jumlah siklus dan $\mathrm{x}$ merupakan jumlah awal molekul DNA. Jadi, seandainya ada 1 kopi DNA sebelum siklus berlangsung, setelah satu siklus akan menjadi 2 kopi, sesudah 2 siklus akan menjadi 4 kopi, dan seterusnya (Hasibuan, 2015). 


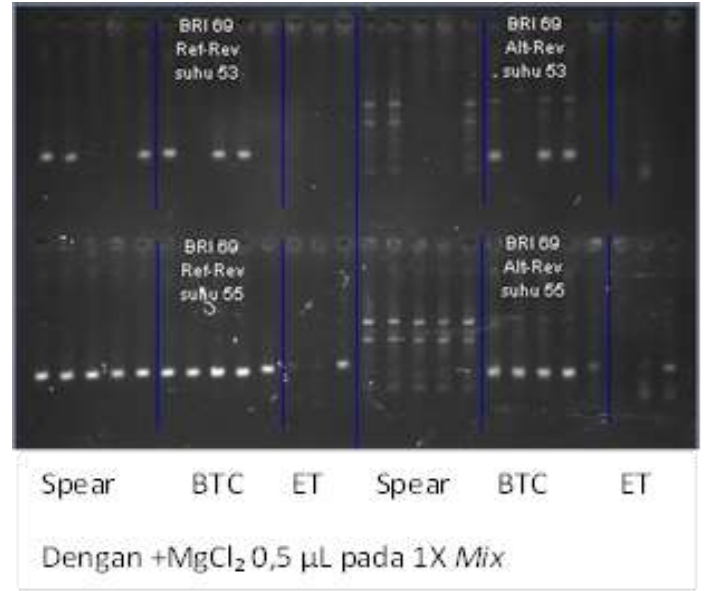

a

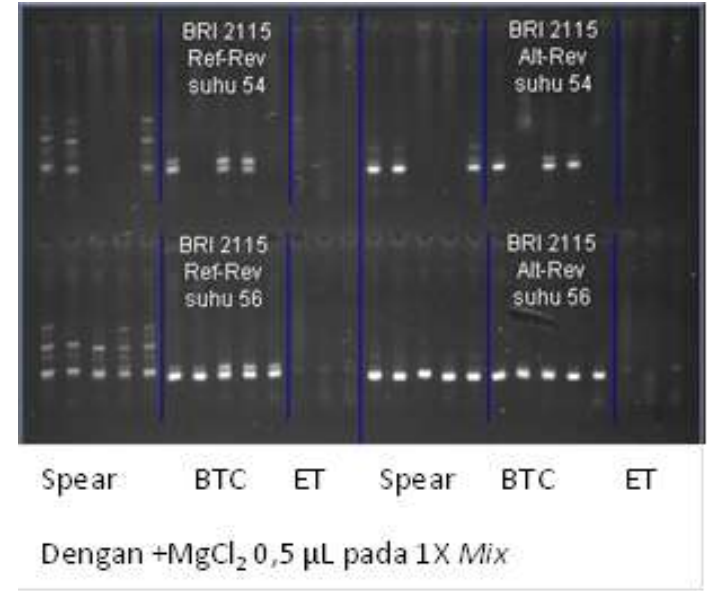

b

Gambar 3. Elektroforesis Agarosa dengan Primer (ditambahan $\mathrm{MgCl}_{2}$ ) (a) BRI 69 Ref-Rev pada suhu $55^{\circ} \mathrm{C}$ dan (b) BRI 2115 Alt-Rev pada suhu $56^{\circ} \mathrm{C}$

Penggunaan enzim Taq DNA Polymerase pada PCR di setiap akhir siklus mengakibatkan penambahan satu nukleotida A pada ujung 3" dari potongan DNA yang dihasilkan. Hasil dari PCR dapat dikloning menggunakan vektor dengan penambahan nukleotida $T$ pada ujung-ujung 5"-nya. Proses PCR dilakukan menggunakan suatu alat yang disebut thermocycler (Hasibuan, 2015). Variasi dilakukan pada pengaturan program suhu annealing karena setiap primer memiliki Tm (melting temperature) optimalnya masing-masing. Hasil dapat diketahui setelah dicek secara elektroforesis menggunakan media gel agarosa. Biasanya primer hasil desain memiliki Tm sekitar 55$65^{\circ} \mathrm{C}$ tergantung dari panjang pasang basa primer hasil desain. Tm dijadikan dasar dalam menentukan suhu annealing. Suhu annealing yang terlalu tinggi akan menyebabkan primer yang menempel pada DNA cetakan terlepas sehingga produk PCR tidak akan terbentuk, sedangkan suhu yang terlalu rendah akan menyebabkan terjadinya penempelan primer yang tidak spesifik pada DNA cetakan. Besarnya suhu annealing ditentukan berdasarkan nilai Tm masingmasing primer yang akan digunakan (Asy'ari dan Noer, 2005).

Konsentrasi ion $\mathrm{Mg}^{2+}$ (bentuk garam $\mathrm{MgCl}_{2}$ ) dalam reaksi PCR dapat divariasi antara 0,5-5,0 mM. Ion $\mathrm{Mg}^{2+}$ memiliki peran dalam pembentukan kompleks dengan dNTP sehingga menjadi semakin larut, peningkatan aktivitas enzim DNA polimerase dan meningkatkan nilai Tm pada untai ganda template DNA maupun interaksi primer-template. Konsentrasi $\mathrm{MgCl}_{2}$ sangat berpengaruh terhadap spesifisitas dan jumlah produk PCR. Jika ion $\mathrm{Mg}^{2+}$ kurang akan menurunkan jumlah produk PCR, sedangkan jika berlebih akan menurunkan spesifisitas dan menghasilkan produk yang tidak spesifik (Asy'ari dan Noer, 2005). Nilai suhu optimum juga dapat dilihat dari nilai GC content (perbandingan guaninsitosin dengan basa nitrogen keseluruhan). Jika GC content-nya tinggi, suhu optimasi akan semakin meningkat karena pada basa $\mathrm{G}$ dan $\mathrm{C}$ terkandung tiga ikatan hidrogen yang memerlukan suhu tinggi untuk memutusnya.

Hasil PCR dicek menggunakan elektroforesis agarosa. Media elektroforesis menggunakan pelarut buffer TAE dan agarosa dengan konsentrasi $1 \%$. Metode elektroforesis digunakan karena murah dan mudah digunakan, serta sudah biasa dilakukan untuk pemisahan DNA dan protein. Pemisahan ini berdasar pada pergerakan molekul-molekul bermuatan di dalam medan listrik (titik isoelektrik). Secara umum sampel makromolekul dielektroforesis melalui beberapa jenis media. Media bertindak sebagai saringan molekuler untuk membantu dalam pemisahan molekul berdasarkan ukuran.

Jenis media pendukung yang digunakan tergantung pada jenis molekul yang akan dipisahkan dan pemisahan berdasarkan muatan, berat molekul atau keduanya. Bahan 
yang biasa digunakan untuk pemisahan asam nukleat dan protein yaitu agarosa dan akrilamida. Pada kegiatan ini digunakan agarosa karena media ini merupakan gel transparan dalam sinar UV (Fuad et al., 2016). Sebagai pemendar DNA saat visualisasi, digunakan GelRed dengan pertimbangan sensitivitas yang lebih baik dan kurang beracun dibandingkan dengan ethidium bromida yang bersifat karsinogenik.

Prinsip GelRed dalam visualisasi DNA adalah GelRed akan menyisip ke dalam basa DNA secara reversibel atau disebut interkalasi. GelRed diinterkalasi antara dua pasangan basa adenin-timin. Ligan dalam GelRed dapat berinteraksi dengan DNA karena adanya muatan negatif pada DNA yang dapat berikatan secara kovalen dengan ligan pada GelRed. GelRed memiliki sifat optik yang pada dasarnya identik dengan ethidium bromida. Ketika terkena sinar ultraviolet, DNA akan berpendar dengan warna oranye setelah mengikat DNA.

\section{KESIMPULAN}

Empat primer Single Nucleotide Amplified Polymorphism (SNAP) yang mendapatkan suhu optimum dengan campuran pereaksi normal yaitu BRI 69 AltRev dan BRI 562 Ref-Rev pada suhu $55^{\circ} \mathrm{C}$, BRI 1206 Alt-Rev pada suhu $57^{\circ} \mathrm{C}$ dan BRI 1206 Ref-Rev pada suhu $58^{\circ} \mathrm{C}$. Dua primer membutuhkan tambahan $\mathrm{MgCl}_{2}$ pada campuran pereaksinya yaitu BRI 69 Ref-Rev pada suhu $55^{\circ} \mathrm{C}$ dan BRI 2115 Alt-Rev pada suhu $56^{\circ} \mathrm{C}$. Pengaruh penambahan $\mathrm{MgCl}_{2}$ pada proses Polymerase Chain Reaction (PCR) adalah penambahan aktivitas enzim DNA polimerase dan menaikkan suhu optimasi primer. Primer yang sudah optimum dapat digunakan untuk pengembangan marka pengatur tinggi batang kelapa sawit lebih lanjut.

\section{DAFTAR PUSTAKA}

Asy'ari, M. \& Noer, A.S. (2005). Optimasi konsentrasi $\mathrm{MgCl}_{2}$ dan suhu annealing pada proses amplifikasi multifragmens mtDNA dengan metoda PCR. Jurnal Kimia dan Sains Aplikasi, 8 (1), 23-27.

Campbell, N.A., Reece, J.B. \& Mitchell, L.G. (2002). Biologi Edisi Kelima: Jilid I. Jakarta: Erlangga.

Corley, R. H. V. \& Tinker, P.B. (2015). Oil Palm: Fifth Edition. West Sussex (UK): John Wiley \& Sons Co., Ltd.

Fuad, A. R. M., Ulfin, I.\& Kurniawan, F. (2016). Penggunaan agar-agar komersial sebagai media gel elektroforesis pada zat warna Remazol: Pengaruh komposisi buffer, pH buffer dan konsentrasi media. Jurnal Sains dan Seni ITS , 5 (2), 2337-3520.

Hasibuan, E. (2015). Peranan Teknik Polymerase Chain Reaction (PCR) Terhadap Perkembangan Ilmu Pengetahuan. Fakultas Kedokteran. Universitas Sumatera Utara, Medan.

Ludyasari, A. (2016). Pengaruh Suhu Annealing pada Program PCR Terhadap Keberhasilan Amplifikasi DNA Udang Jari (Metapenaeus elegans De Man, 1907) Laguna Segara Anakan, Cilacap, Jawa Tengah (Skripsi). Fakultas Sains dan Teknologi. Universitas Islam Negeri Maulana Malik Ibrahim Malang, Malang.

Macherey-Nagel. (2015). Genomic DNA from Plant: User Manual of Nucleospin ${ }^{\circledR}$ Plant II. MachereyNagel GmbH \& Co. KG. Dueren (Germany).

Mubarok, A.F. (2015). Validasi Single Nucleotide Polymorphisms (SNP) Berbasis Genom dan Pemanfaatannya untuk Uji Kekerabatan 50 Aksesi Kedelai (Skripsi). Fakultas Matematika dan Ilmu Pengetahuan Alam. Institut Pertanian Bogor, Bogor. 
Natawijaya, A. (2018). Keragaman dan struktur genetik plasma nutfah kelapa sawit koleksi Taman Buah Mekarsari berdasarkan karakter agronomi dan marka mikrosatelit (Tesis). Sekolah Pascasarjana. Institut Pertanian Bogor. Bogor.

Suguna, S., Nandal, D. H., Kamble, S., Bharatha, A., \& Kunkulol, R. (2014). Genomic DNA isolation from human whole blood samples by non enzymatic salting out method. International Journal of Pharmacy and Pharmaceutical Sciences, 6 (6), 198-199.
Susanto, A., Hermanto, C. Sukma, D. \& Sudarsono. (2013). Pengembangan marka SNAP berbasis Resistance Gene Analogue pada tanaman pisang (Musa spp.). Jurnal Hortikultura, 23 (4), 300-309.

Syafaruddin, Randriani, E. \& Santoso, T. J. (2011). Efektivitas dan Efisiensi Teknik Isolasi dan Purifikasi DNA pada Jambu Mete. Buletin RISTRI, 2 (2), 151-160. 